\title{
Reformulasi domain hukum ideologi Pancasila oleh Badan Pembinaan Ideologi Pancasila
}

\section{Ferry Anggriawan}

Ferry Anggriawan; Fakultas Hukum Universitas Merdeka Malang; Jalan Terusan Dieng No 62-64; Malang; 60286; Jawa Timur; Indonesia.

\section{ARTICLEINFO}

\section{Article history:}

Received 2020-01-14

Received in revised form

2020-02-11

Accepted 2020-04-01

\section{Kata kunci:}

Pancasila; Status Hukum;

Reformulasi.

\section{Keywords:}

Pancasila; Legal Status;

Reformulation.

DOI: https://doi.org/10.26905/

idjch.v11i1.4045.

\section{How to cite item:}

Anggriawan, F. (2020). Reformulasi domain ideologi Pancasila oleh Badan Pembinaan Ideologi Pancasila. Jurnal Cakrawala Hukum, 11(1), 31-40. doi:10.26905/ idjch.v11i1.4045.

Corresponding Author:

* Ferry Anggriawan.

E-mail address: fanggriawan11@gmail.com

\section{Abstrak}

Diundangkannya Peraturan Presiden No 7 Tahun 2018 tentang Badan Pembinaan Ideologi Pancasila secara otomatis mengakibatkan status hukum Ideologi Pancasila bukan hanya sebagai dasar negara, tetapi sebagai ideologi negara yang disahkan melalui Peraturan Presiden No 7 Tahun 2018 tentang Badan Pembinaan Ideologi Pancasila. Fakta hukum yang terjadi adalah terjadi kekosongan hukum terkait substansi pengaturan domain hukum Ideologi tersebut. Akibatnya adalah Badan Pembinaan Ideologi Pancasila (BPIP) yang diberikan kewenangan membina masyarakat terkait ideologi Pancasila, tidak diberikan landasan hukum dalam hal substansi ideologi yang akan disampaikan. Reformulasi pengaturan substansi ideologi Pancasila sangat diperlukan dalam masalah ini, disatu sisi menjamin kepastian hukum atas domain hukumnya, disisi lain ideologi harus diterapkan sesuai dengan akar sejarah, filosofi dan hukum positif yang ada di Indonesia.

\section{Abstract}

The promulgation of Presidential Regulation No. 7 of 2018 concerning the Pancasila Ideology Development Agency automatically results in the legal status of the Pancasila Ideology not only as the basis of the state, but as a state ideology that was ratified through Presidential Regulation No. 7 of 2018 concerning the Pancasila Ideology Development Agency. The legal facts that occur are legal vacancies related to the substance of the ideology's legal domain regulation. The result is that the Pancasila Ideology Development Board (BPIP) which has been given the authority to foster the community in relation to the Pancasila ideology, is not given a legal basis in terms of the ideological substance to be conveyed. Reformulation of the regulation of Pancasila ideology substance is very much needed in this matter, on the one hand it guarantees legal certainty over its legal domain, on the other hand ideology must be applied in accordance with historical roots, philosophies and positive laws that exist in Indonesia. 


\section{Jurnal Cakrawala Hukum, Volume 11 No. 1 April 2020}

ISSN PRINT 2356-4962 ISSN ONLINE 2598-6538

\section{Latar Belakang}

Pembukaan Undang-Undang Dasar Negara Republik Indonesia Tahun 1945 telah mencantumkan sekaligus melegitimasi bahwa 5 butir sila yang terkandung dalam Pancasila merupakan bagian dari pembukaan konstitusi kita, yang secara otomatis memberikan status yang jelas bahwa Pancasila adalah bagian dari hukum positif yang ada di Indonesia. Selain dinyatakan sebagai hukum positif di Indonesia Pancasila juga dianggap sebagai filsafat, weltanschaung dan ideologi (Driyarkara, 1980) hingga Pancasila adalah dasar negara (Ridwan, 2018).

Fakta hukum yang terjadi selanjutnya adalah Pancasila bisa diterapkan melalui dua status dan fungsinya hal ini diperkuat oleh Presiden Joko Widodo dengan menerbitkan Peraturan Presiden No 7 Tahun 2018 tentang Badan Pembinaan Ideologi Pancasila di bagian menimbang huruf a Peraturan Presiden No 7 Tahun 2018 tentang Badan Pembinaan Ideologi Pancasila yang menyatakan bahwa:

"Pancasila sebagai dasar dan ideologi negara, sejak kelahirannya pada tanggal 1 Juni 1945, sebagaimana ditetapkan melaiui Keputusan Presiden Nomor 24 Tahun 2016 tentang Hari Lahir Pancasila, harus ditegakkan dan diamalkan dalam berbagai sendi kehidupan bermasyarakat, berbangsa dan bernegara"

Secara Eksplisit telah disebutkan di atas bahwa Pancasila adalah Dasar Negara dan Ideologi Negara. Mengenai rentetan waktunya juga disebutkan bahwa sejak kelahirannya pada tanggal 1 Juni 1945. Pancasila sebagai dasar negara dapat dijelaskan melalui beberapa Pasal yang tertulis dalam Konstitusi diantaranya Pasal 28 UndangUndang Dasar negara Republik Indonesia Tahun 1945 mengatur tentang hak asasi manusia Pasal 29 Undang-Undang Dasar negara Republik Indonesia Tahun 1945 mengatur tentang agama dan Pasal
33 Undang-Undang Dasar negara Republik Indonesia Tahun 1945 mengatur ekonomi dan kesejahteraan sosial serta turunan undang-undang dibawahnya yang lebih spesifik mengatur pelaksanaannya.

Permasalahan yang terjadi adalah status Pancasila yang kedua, yaitu sebagai ideologi negara yang akan segera dimplementasikan kepada seluruh warga negara Indonesia dengan payung hukum Peraturan Presiden no 7 Tahun 2018 tentang Badan Pembinaan Ideologi Pancasila. Peraturan Presiden tersebut hanya mengatur terkait mekanisme administrasi seperti; tugas Badan Pembinaan Ideologi Pancasila (BPIP), fungsi BPIP, susunan organisasi dan struktural organisasi. Hal-hal yang mengatur mengenai domain hukum ideologi Pancasila dan ideologi seperti apa yang direncanakan kelak yang selanjutnya dijadikan objek pembinaan terhadap seluruh bangsa Indonesia, tidak dimasukkan dalam Peraturan Presiden tersebut.

Kasus hukum yang terjadi terkait kekosongan hukum substansi ideologi Pancasila adalah ketika kepala BPIP memberikan pernyataan bahwa agama adalah musuh Pancasila (vivanews.com). Meskipun dalam klarifikasinya beliau menyatakan bahwa orang yang mempolitisasi agama untuk kepentingan politiknya itulah yang dikategorikan sebagai musuh Pancasila. Kejadian ini adalah fakta bahwa BPIP memang diberikan kewenangan membina ideologi Pancasila kepada masyarakat tetapi BPIP tidak diberikan legalitas terkait substansi ideologi yang akan disampaikan kelak. Akibatnya justifikasi yang disampaikan sangat bertentangan dengan nilai-nilai yang ada dalam Pancasila.

Latar belakang yang telah disampaikan di atas, penulis rumuskan permasalahan yang akan di bahas dalam jurnal ini yaitu; bagaimana seharusnya reformulasi hukum Ideologi pancasila yang akan disampaikan dan dibinakan terhadap warga negara Indonesia? 


\section{Reformulasi domain hukum ideologi Pancasila oleh Badan Pembinaan Ideologi Pancasila}

Ferry Anggriawan

\section{Metode}

Penelitian ini menggunakan metode penelitian yuridis normatif dengan pendekàtàn undàngundang (Statuta Approach), pendekatan historis dan pendekatan filosofis. Harapan dari penelitian ini adalah segera diberikan legalitas terkait substansi pengaturan domain ideologi Pancasila yang mencerminkan nilai-nilai historis pada saat perumusannya dan mempunyai nilai filosif dalam penerapannya. Agar kelak tidak ada lagi justifikasi yang dilakukan oleh BPIP yang bertentangan dengan nilai historis Pancasila dan bertentangan dengan aktualisasi ideologi Pancasila.

\section{Pembahasan}

\subsection{Rerformulasi ideologi Pancasila terhadap Badan Pembinaan Ideologi Pancasila}

Isu hukum dalam permasalahan ini adalah adanya kekosongan hukum substansi ideologi Pancasila, yang akan dijadikan objek pembinaan oleh BPIP kepada masyarakat Indonesia. Ideologi adalah ilmu yang mempelajari pengertian dasardasar ide atau ajaran mengenai pengertian-pengertian dasar. Ide juga termasuk cita-cita yang bersifat tetap dan harus dicapai (Syamsudin, 2009). Ideologi Pancasila adalah suatu gagasan yang digali melalui sejarah terbentuknya Pancasila kemudian di konsepkan melalui 5 butir sila, sebagai pengertian dasar cita-cita negara yang harus dicapai. Reformulasi Ideologi Pancasila harus memenuhi 3 unsur nilai dasar yang harus ada dan kemudian diterapkan, ketiga unsur dasar itu adalah sejarah Pancasila, filsafat Pancasila dan Pancasila sebagai dasar negara.

\subsection{Sejarah dan ide awal perumusan Pancasila}

Pancasila lahir dilatar belakangi oleh banyaknya ideologi negara yang berkembang saat itu, seperti Komunisme, Fasisme, Liberalisme, belum juga bentuk negara yang ada dan berkembang saat itu seperti negara komunis, demokrasi, kerajaan. Soekarno menyatakan bahwa dia bukanlah pencipta Pancasila, tetapi beliaulah yang menggali tradisi-tradisi yang ada di Indonesia dan menemukan lima butir yang indah yaitu Pancasila (Adams, 2018)

Soekarno memenuhi permintaan Ketua Panitia Badan Penyelidik Usaha-Usaha Persiapan Kemerdekaan Indonesia (BPUPKI) dr. Radjiman Wedjodiningrat Pada bulan April 1945 untuk mencari dan menemukan dasar Negara Indonesia Merdeka (Hatta 1978). Pada sidang tersebut Soekarno mengupas lima mutiara berharga yaitu; Kebangsaan Internasionalisme atau Perikemanusiaan, Demokrasi, Keadilan Sosial dan Ketuhanan Yang Maha Esa.

Mutiara pertama; Kebangsaan diuraikan sebagai berikut "aku menjelaskan, hari depan kami harus berdasar pada Kebangsaan, karena "orang dan tempat tidak dapat dipisahkan! Tidak dapat dipisahkan rakyat dari bumi yang ada di bawah kakinya." Batas-batas kebangsaan diuraikan dengan menyatakan bahwa luas wilayah Indonesia adalah semua orang yang tinggal di seluruh kepulauan Indonesia dari Sabang sampai Merauke (Adams, 2018).

Mutiara kedua; Internasionalisme diuraikan sebagai berikut "Indonesia hanya satu bagian kecil saja dari dunia. Ingatlah kata-kata Ghandi, saya seorang nasionalis, tetapi kebangsaan saya adalah perikemanusiaan. Nasionalisme tidak dapat hidup subur, kalau tidak hidup dalam taman sarinya Internasionalisme.

Mutiara ketiga; Demokrasi diuraikan sebagai berikut "selama berabad-abad negeri kami hidup dengan kebiasaan asli berupa musyawarah dan mufakat. Ini adalah perundingan demokratis model Asia. Sebagai seorang yang meyakini bahwa kekuatan terletak dalam pemerintahan atas dasar perwakilan, aku berkata, "Kita tidak akan menjadi negara untuk satu orang atau satu golongan" 
tetapi "semua buat semua, satu buat semua, semua buat satu. "Biarlah orang-orang Islam bekerja sehabat-hebatnya, agar supaya sebagian tersebar di kursi-kursi Dewan Perwakilan Rakyat diduduki oleh utusan -utusan Islam. "Kalau misalnya orang Kristen ingin bahwa tiap-tiap peraturan dari Negara Indonesia dijiwai oleh Injil, bekerjalah mati-matian, agar supaya sebagian besar dari utusan-utusan adalah orang Kristen. Itu adil!".

Mutiara keempat adalah Keadilan Sosial, dengan uraian sebagai berikut; "apakah kita mau merdeka yang kaum kapitalisnya merajalela, ataukah semua rakyatnya sejahtera, karena merasa diayomi oleh Ibu Pertiwi yang cukup memberi sandang pangan kepadanya?. Kita mengharapkan datangnya Ratu Adil, yaitu Keadilan Sosial. Kita tidak menghendaki persamaan politik semata, kita ingin Demokrasi Sosial, Demokrasi Ekonomi. Satu dunia baru di dalam mana terdapat kesejahteraan bersama.".

Mutiara yang kelima adalah Ketuhanan Yang Maha Esa, dengan uraian sebagai berikut; "marilah kita menyusun Indonesia merdeka dengan bertaqwa kepada Tuhan Yang Maha Esa", "tetapi biarkan masing-masing orang Indonesia bertuhan Tuhannya sendiri. Hendaknya tiap-tiap orang menjalankan ibadahnya sesuai cara yang dipilihnya. Marilah kita jalankan asas kelima dengan cara yang berkeadaban; percaya kepada Tuhan Yang Maha Esa dengan hormat menghormati satu sama lain.".

Rumusan formal yang diajukan oleh Soekarno pada tanggal 1 Juni 1945 kemudian kemudian direformulasikan oleh Panitia Sembilan menjadi Piagam Djakarta selanjutnya disahkan sebagai rumusan legal-final dasar negara dalam Pembukaan Undang-Undang Dasar Negara Repu-

Tabel 1.1 Era sebelum kemerdekaan (Wahana, 1993)

\begin{tabular}{|c|c|c|}
\hline Rumusan & Status & Urutan \\
\hline $\begin{array}{l}\text { a. Rumusan Pancasila muncul karena adanya } \\
\text { semangat nasionalisme yang tinggi pada } \\
\text { saat itu seperti bedirinya beberapa partai } \\
\text { seperti PNI. Selanjutnya adalah bangkitnya } \\
\text { kesadaran ideologis yang bertujuan untuk } \\
\text { mencitakan kesatuan tanah air, bangsa dan } \\
\text { bahasa indonesia ditandai dengan } \\
\text { dilaksanakannya Kongres Pemuda } \\
\text { Indonesia Tahun 1928. Puncak dari } \\
\text { rumusan ideologi tersebut adalah ketika } \\
\text { Soekrano menyampaikan rumusan } \\
\text { Pancasila dalam sidang BPUPKI. } \\
\text { b. Rumusan oleh Soekarno kemudian } \\
\text { dirumuskan kembali oleh Panitia } 9 \text { untuk } \\
\text { dijadikan sebagai Piagam Djakarta }\end{array}$ & $\begin{array}{l}\text { Konsensus } \\
\text { Nasional }\end{array}$ & $\begin{array}{l}\text { 1. Ketuhana, dengan kewajiban } \\
\text { menjalankan syariat Islam bagi } \\
\text { pemeluk-pemeluknya. } \\
\text { 2. Kemanusiaan yang adil dan beradab } \\
\text { 3. Persatuan Indonesia } \\
\text { 4. Kerakyatan yang dipimpin oleh } \\
\text { hikmat dalam permusyawaratan } \\
\text { perwakilan } \\
\text { 5. Keadilan sosial bagi seluruh rakyat } \\
\text { Indonesia }\end{array}$ \\
\hline
\end{tabular}




\section{Reformulasi domain hukum ideologi Pancasila oleh Badan Pembinaan Ideologi Pancasila}

Ferry Anggriawan

blik Indonesia Tahun 1945. Selanjutnya, rumusan Pancasila sempat berubah bentuknya menjadi rumusan UUDS pada saat pemerintahan berganti menjadi Republik Indonesia Serikat untuk menudian kembali lagi menjadi Undang-Undang Dasar Negara Republik Indonesia Tahun 1945 melalui Dekrit Presiden 5 Juli 1959 (Poespowardojo 1989).Perubahan rumusan dan urutan serta status Pancasila telah mengalami perubahan bentuk selama beberapa kali mulai dari rumusan awal oleh Soekarno, Mohammad Yamin, Soepomo, hingga rumusan yang terkandung dalam pembukaan Undang-Undang Dasar Negara Republik Indonesia Tahun 1945. Terakhir rumusan dan urutan kelima sila sebagaimana diamandatkan melalui dekrit Presiden Soekarno ditegaskan lagi oleh Presiden Soeharto melalui Instruksi Presiden No 12. Tahun 1968 tentang Keseragaman Rumusan dan Urutan sila-Sila. Berikut ini adalah tabel yang membahas perubahan status, rumusan dan urutan Pancasila.

Era Pemerintahan Presiden Joko Widodo status Pancasila bukan hanya sebagai dasar negara yang terdapat dalam alenia Pembukaan UndangUndang Dasar Negara Republik Indonesia Tahun 1945, tetapi status Pancasila telah legal dinyatakan sebagai Ideologi Negara melalui Badan yang dibentuk oleh pemerintahan saat ini yaitu Badan Pembinaan Ideologi Pancasila. Garis besar halauan Ideologi Pancasila (bpip.go.id) meliputi;

Tabel 1.2 Era setelah kemerdekaan (Hatta, 1978)

\begin{tabular}{|c|c|c|}
\hline Rumusan & Status & Urutan \\
\hline $\begin{array}{l}\text { a. Rumusan setelah proklamasi kemerdekaan } \\
\text { tepatnya pada tanggal } 18 \text { Agustus } 1945 \\
\text { PPKI menghapus anak kalimat "dengan } \\
\text { kewajiban menjalankan syariat Islam bagi } \\
\text { pemeluknya", dengan menetapkan } \\
\text { rumusan dan sila yang lain untuk } \\
\text { dimasukkan dalam pembukaan UUD NRI } \\
\text { Tahun } 1945 \text { alinea IV. }\end{array}$ & $\begin{array}{l}\text { Dasar } \\
\text { negara } \\
\text { (Konstitusi) }\end{array}$ & $\begin{array}{l}\text { 1. Ketuhanan yang maha esa } \\
\text { 2. Kemanusiaan yang adil dan beradab } \\
\text { 3. Persatuan Indonesia } \\
\text { 4. Kerakyatan yang dipimpin oleh hikmat } \\
\text { kebijaksanaan dalam permusyawaratan } \\
\text { perwakilan } \\
\text { 5. Keadilan sosial bagi seluruh rakyat } \\
\text { Indonesia }\end{array}$ \\
\hline $\begin{array}{l}\text { b. Pada } 1950 \text { pada era Republik Indonesia } \\
\text { Serikat, rumusan dan urutan Pancasila } \\
\text { mengalami beberapa perubahan }\end{array}$ & $\begin{array}{l}\text { Dasar } \\
\text { Negara } \\
\text { (Konstitusi) }\end{array}$ & $\begin{array}{l}\text { 1. Ketuhanan yang maha esa } \\
\text { 2. Perikemanusiaan } \\
\text { 3. Kebangsaan } \\
\text { 4. Kerakyatan } \\
\text { 5. Keadilan Sosial }\end{array}$ \\
\hline $\begin{array}{l}\text { Dekrit Presiden } 1959 \text { menyatakan bahwa } \\
\text { rumusan Pancasila pada UUD RIS tidak } \\
\text { diberlakukan lagi dan kembali pada UUD } \\
\text { NRI Tahun 1945. ketentuan hukum } \\
\text { tersebut kemudian ditegaskan lagi oleh } \\
\text { Instruksi Presiden No } 12 \text { Tahun } 1968 \\
\text { tentang Keseragaman rumusan dan urutan } \\
\text { sila-sila. }\end{array}$ & $\begin{array}{l}\text { Dasar } \\
\text { Negara } \\
\text { (Konstitusi) }\end{array}$ & $\begin{array}{l}\text { 1. Ketuhanan yang maha esa } \\
\text { 2. Kemanusiaan yang adil dan beradab } \\
\text { 3. Persatuan Indonesia } \\
\text { 4. Kerakyatan yang dipimpin oleh hikmat } \\
\text { kebijaksanaan dalam permusyawaratan } \\
\text { perwakilan } \\
\text { 5. Keadilan sosial bagi seluruh rakyat } \\
\text { Indonesia }\end{array}$ \\
\hline
\end{tabular}




\section{Jurnal Cakrawala Hukum, Volume 11 No. 1 April 2020}

ISSN PRINT 2356-4962 ISSN ONLINE 2598-6538

a. Status Pancasila adalah sebagai dasar negara, pandangan hidup dan sebagai ideologi

b. Untuk melaksanakan pembangunan harus ada pemahaman benar tentang Pancasila yang diwujudkan melalui Pembangunan Nasional untuk Masyarakat adil dan Makmur

c. Pokok pemikiran Pancasila adalah berdaulat dibidang politik, berdiri di atas kaki sendiri di bidang ekonomi dan berkepribadian dalam kebudayaan

d. Target pembangunan melalui Garis Besar Haluan Ideologi Pancasila adalah (i) Mental agama, pendidikan, kebudayaan (ii) Kesejahteraan dan Kesehatan (iii) Pemerintahan, Pertahanan Keamanan (iv) Pengelolaan sumber daya alam dan linkungan hidup (v) Hukum dan Penegakan HAM (vi) Produksi dan Pertanahan (vii) Bidang keuangan dan penganggaran (viii) Bidang Distribusi dan Perhubungan.

Di era pemerintahan Presiden Joko Widodo, status Pancasila bukan hanya sebagai dasar negara yang termaktub dalam Konstitusi, melainkan status tersebut ditambah sebagai sebuah ideologi negara yang dilembagakan melalaui Badan Pembinaan Ideologi Pancasila. Konfigurasi politik pada saat sebelum kemerdekaan dan pasca kemerdekaan telah mempengaruhi kristalisasi status dan urutan Pancasila pada saat itu. Tetapi yang perlu digaris bawahi adalah secara substansial dasar pemikiran dari mulai sidang BPUPKI, PPKI hingga sekarang, nilai dasar yang telah digali oleh Soekarno tetap menjadi dasar pemikiran yang akan dijadikan cita-cita bangsa dalam bernegara.

Cita-cita itu adalah lima prinsip dasar yang dipegang teguh oleh Negara Kesatuan Republik Indonesia yaitu; ketuhanan yang maha esa yang melahirkan kebebasan memeluk agama dan kepercayaan kepada warga negaranya, kebangsaan yang melahirkan konsep pengakuan atas jatidiri kita sebagai bangsa Indonesia, kemanusiaan (internasionalisme) menghasilkan pemikiran status kita sebaga warga negara Indonesia tidak bisa dilepaskan dari sifat kemanusiaan yang itu tidak hanya diterapkan sesama bangsa Indonesia tetapi sesama manusia yang ada diseluruh dunia, demokrasi yang melahirkan pemikiran bahwa setiap permasalahan harap diselesaikan melalui mekanisme musyawarah mufakat dan keadilan sosial yang memberikan dasar pemikiran dan citacita bahwa negara tidak boleh mensejahterahkan kaum kapitalis saja, tetapi semua kesejahteraan bangsa Indonesia harus disejahterahkan.

\subsection{Filsafat Pancasila}

Pancasila adalah konsensus leluhur pendiri bangsa antar semua golongan yang ada di Indonesia. Oleh karena itu setiap warga negara Indonesia terikat dengan ketentuan-ketentuan yang sangat mendasar yaitu; menyepakati kelima sila tersebut, bukan hanya masing-masing sila. Seluhur apapun sebuah konsensus maka tidak akan berfungsi jika tidak ditempatkan dalam status yang jelas (Wahid, 1991).

Penempatan status Pancasila dapat didudukkan dalam beberapa hal; pertama, Pancasila sebagai ideologi bangsa dan falsafah negara. Pancasila dijadikan kerangka berfikir yang harus diikuti dalam undang-undang dan produk-produk hukum lainnya. Tata pikir seluruh bangsa ditentukan oleh falsafah yang harus dijaga keberadaan dan eksistensinya oleh negara. Kedua Pancasila sebagai falsafah dan ideologi bangsa. Harus jelas dikatakan bahwa adanya tumpang tindih antara Pancasila dengan sisi kehidupan beragama dan kepercayaan terhadap Tuhan Yang Maha Esa. Makna kepercayaan terhadap Tuhan Yang Maha Esa adalah adanya unsur-unsur universal (meskipun secara teologis setiap agama dan kepercayaan mengandung unsur yang ekslusif) yang perlu ditekankan adalah sisi universalnya melalui sikap toleransi. 


\section{Reformulasi domain hukum ideologi Pancasila oleh Badan Pembinaan Ideologi Pancasila}

Ferry Anggriawan

Aktualisasi dari sikap toleransi dapat dilakukan dengan indenpendensi teologis kebenaran masing-masing agama dan kepercayaan. Pancasila hendaknya menjadi "polisi lalu lintas" dalam kehidupan beragama dan berkepercayaan. Secara legalitas hendaknya semua agama diperlakukan sama oleh undang-undang dan tidak boleh ditundukkan oleh kepercayaan dan agama-agama yang ada, begitu juga sebaliknya tidak boleh ada agama dan kepercayaan yang saling mengkontradiksi satu sama lain.

Hal tersebut akan menimbulkan ketegangan, tetapi ketengan tersebut harap disikapi melalui ketegangan kreatif dalam berbangsa dan bernegara. Maksud dari ketegangan kreatif adalah suatu kelapangan dada dan toleransi dalam lalu lintas kebangsaan yang kreatif untuk kemajuan dan pengembangan kualitas bangsa Indonesia. Ketegangan kreatif itulah kita dapat mengembangkan pemikiran terkait nilai-nilai dasar kehidupan bangsa dan negara. Nilai dasar tersebut dapat ditarik melalui dua arah. Pertama, nilai-nilai agama dan kepercayaan karena ajaran keagamaan akan tetap menjadi referensi umum bagi Pancasila. Kedua, agama-agam dan kepercayaan harus memperhitungkan eksistensi Pancasila sebagai "polisi lalu lintas" yang bisa menjamin semua pihak bisa menggunakan jalan raya kehidupan bangsa tanpa terkecuali.

Secara epistimologis Pancasila bukan hanya dapat ditemukan dalam diri manusia Indonesia sebagaimana diakui oleh Presiden Soekarno tetapi juga melekat dalam kodrat manusia pada umumnya (Drijarkara, 1980). Penelitian feminologis terhadap kodrat manusia menunjukkan bahwa manusia pada dasarnya terhubung dalam segalanya. Manusia tidak bisa hidup sendiri. Eksistensi seorang manusia dapat diakui karena adanya manusia yang lain, tanpa yang lain, manusia nihil. Kesadaran akan sosialitas manusia itu tampak dalam hubungannya dengan alam jasmani, alam rohani , sesama manusia dan akhirnya tuhan. Berikut pen- jelasan makna perikemanusiaan, keadilan sosial, demokrasi dan kebangsan, serta prinsip ketuhanan yang mencakup keempat nilai tersebut.

a. Perikemanusiaan: Prinsip Umum Pancasila Syarat yang harus dipenuhi sebagai seorang manusia sesuai dengan kodratnya yaitu manusia harus bersatu dengan alam jasmani dan hidup bersama dengan sesama manusia. Kesatuan keduanya tersebut harus dijalankan dengan rasa cinta. Pengakuan dan tuntutan kodrati tersebut disebut perikemanusiaan. Perikemanusiaan merupakan pelaksanaan cinta terhadap sesama manusia sebagai pribadi yang mesti diakui dan dihormati. Cinta tanpa pengakuan dan penghormatan adalah nihil (Driyarkara, 1977)

b. Keadilan Sosial, Demokrasi dan Kebangsaan: Pelaksanaan Perikemanusiaan

Penjabaran dari prinsip perikemanusiaan adalah adanya keadilan sosial, demokrasi dan kebangsaan. Prinsip keadilan sosial sebagai perikemanusiaan adalah prinsip keadilan di bidang ekonomi yang muncul ketika manusia mulai memberdayakan alam jasmani untuk memenuhi kebutuhan hidup. Karena prinsip kemanusiaan adalah ada bersama dalam cinta kasih, maka setiap peralatan, perlengkapan dan syarat-syarat hidup harus bisa memanusiakan manusia, baik secara pribadi maupun bersama-sama.

Penjabaran dari makna demokrasi adalah kehidupan bermasyarakat itu ada karena kodrat manusia selalu ada bersama dan akibat dari kebersamaan itu memunculkan masyarakat. Karena selalu bersama maka muncullah cinta dan kasih, maka fundamen masyarakat adalah cinta dan kasih (Baghi, 2016). Pemikiran ini muncul dikarenakan adanya pemikiran terkait perbandingan antar demokrasi dan diktatorisme. Berbeda dengan diktatorisme yang memerlukan warga bukan sebagai manusia melainkan barang, demokrasi menempat- 


\section{Jurnal Cakrawala Hukum, Volume 11 No. 1 April 2020}

ISSN PRINT 2356-4962 ISSN ONLINE 2598-6538

kan warga sebagai pribadi yang utuh. Sebagai pribadi ia memiliki hak-hak asasi tertentu yang harus dihormati oleh negara. Tujuannya adalah masyarakat dapat menggunakan hak tersebut untuk aktifitas bernegara.

Penjabaran terkait kebangsaan adalah ada bersama adalah kodrat manusia, tetapi manusia hanya sanggup membentuk ada bersama dalam suatu kelompok kecil tertentu. Beberapa faktor yang melatarbelakngi manusia untuk hidup bersama adalah suku, keadaan geografis, iklim dan sejarah yang sama. Ada bersama dalam nasib yang sama dan kesamaan sejarah itulah yang disebut bangsa (Dakidae, 2003). Rumusan yang lebih padat adalah "komunitas politis dan dibayangkan sebagai sesuatu yang bersifat terbatas secara inheren sekaligus berkedaulatan. Akibat dari persamaan nasib, sejarah dan perlunya suatu kedaulatan karena adanya persentuhan dengan bangsa lain, maka diperlukan konsep nasionalisme, tanpa persentuhan dengan bangsa lain maka tidak akan muncul prinsip nasionalisme. Jadi kebangsaan memunculkan semangat nasionalisme yang tujuannya adalah mewujudkan prinsip kemanusiaan.

Penjabaran yang terakhir adalah prinsip ketuhanan sebagai dasar kemanusiaan, keadilan sosial, demokrasi dan kebangsaan. Penempatan posisi atau urutan antar sila dalam Pancasila memang menempatkan sila Ketuhanan Yang Maha Esa sebagai sila pertama bahkan yang termaktub dalam Mukaddimah Undang-Undang Dasar Negara Republik Indonesia Tahun 1945. Secara genealogis, ide tentang prinsip ketuhanan muncul setelah ide kemanusiaan, keadilan sosial, demokrasi dan kebangsaan. Tuhan memang diakui dalam realitas pertama, tetapi faktanya kesadaran realitas pertama yang dilakukan oleh manusia adalah menye- lidiki barang-barang dari alam jasmani. Dalam penyelidikan itu manusia menemukan suatu keter- batasan dalam diri. Ia dan alam bukanlah sesuatu yang final, ada sesuatu yang mutlak yaitu sumber dari segala sumber, dari situlah muncullah pemi- kiran terkait ketuhanan. Konstruksi pemikiran yang dibangun dalam makna ketuhanan dalam konsep ini adalah asalkan manusia mau berfikir serius tentang diri sendiri dan alam, maka ia akan sampai kepada tuhan.

Secara filosofi lima butir sila yang tercantum dalam Pancasila adalah berkaitan satu sama lain. Tidak bisa Pancasila hanya diterapkan satu sila satu saja dan status Pancasila ketika dijadikan dasar negara atau ideologi negara hendaknya produk hukum tersebut harus sesuai dengan nilai-nilai filosofis Pancasila itu sendiri. Nilai filosofis yang pertama; Pancasila mengedepankan nilai sosiologis dari pada teologis antar warga negaranya, kenapa? Karena Pancasila memberikan jaminan kebebbasan memeluk agama dan kepercayaan terhadap warga negaranya. Kedua Pancasila itu ada bukan hanya disetiap diri manusia Indonesia tetapi disetiap diri manusia yang menjadikan dasar pemikiran kemanusiaan (internasionalisme) karena manusia terhubung satu sama lain. Ketiga keadilan sosial, kesejahteraann dan demokrasi hendaknya tidak bertentangan dengan nilai-nilai kemanusiaan dan yang keempat adalah dalam beragama juga harus mengedepankan kemanusiaan dengan ide yang ditawarkan sebagai berikut; asalkan manusia mau berfikir serius terhadap manusia dan alam maka ia akan sampai pada tuhan, karena setiap pemikiran manusia pasti ada batasannya ia dan alam bukanlah sesuatu yang mutlak dan sesuatu yang mutlak yaitu Tuhan.

\subsection{Pancasila sebagai dasar negara}

Status Pancasila sebagai dasar negara tidak bisa dilepaskan dari konsensus pendiri bangsa yang memasukkan Pancasila sebagai bagian dari mukaddimah Undang-Undang Dasar Negara Republik Indonesia Tahun 1945. Kedudukan Pancasila sebagai bagian dari Konstitusi, maka secara otomatis Pancasila adalah bagian dari hukum positif di Indonesia. 


\section{Reformulasi domain hukum ideologi Pancasila oleh Badan Pembinaan Ideologi Pancasila}

Ferry Anggriawan

Penjelasan makna setiap sila dan keterkaitan antara sila yang satu dengan lainnya tidak dijelaskan dalam bagian penjelasan Undang-Undang Dasar Negara Republik Indonesia Tahun 1945. Tetapi dalam bab 1 sampai 16 pasal-pasal yang dicantumkan merupakan ceriminan nilai dari Pancasila dan seluruh yang tertuang dalam pembukaan Undang-Undang Dasar Negara Republik Indonesia Tahun 1945. Terkait ketuhanan; negara berdasar kepada Tuhan yang maha esa dan negara memberikan jaminan kemerdekaan kepada warga negaranya untuk memeluk agamanya masingmasing dan beribadah menurut agama dan kepercayaan masing-masing (Pasal 29 UUD NRI 1945).

Terkait kemanusiaan; diatur dalam bab Hak Asasi Manusia sekaligus memberikan jaminan kemerdekaan terhadap mempertahankan hidup dan kehidupannya, hidup dan berkembang tanpa adanya diskriminasi, pengakuan, jaminan dan perlindungan hukum serta perlakuan sama di mata hukum, memperoleh kesempatan yang sama di pemerintahan dan setiap orang wajib menghormati hak asasi manusia lain dalam kehidupan bermasyarakat, berbangsa dan bernengara (Pasal 28 UUD NRI 1945).

Terkait kebangsaan; menyatakan bahwa yang menjadi warga negara Indonesia adalah orangorang bangsa Indonesia dan orang-orang bangsa lain yang disahkan dengan undang-undang sebagai warga negara (Pasal 26 dan 27 UUD NRI Tahun 1945). Terkait demokrasi; konsensus pendiri negara kita sepakat bahwa bentuk negara adalah Negara Kesatuan Republik Indonesia dan dilegitimasi melalui konstitusi, kedaulatan berada di tangan rakyat, dan negara Indonesia adalah negara hukum (Pasal 1 UUD NRI 1945).

Terkait kesejahteraan sosial; fakir miskin dan anak terlantar dipelihara oleh negara, negara mengembangkan sistem jaminan sosial bagi seluruh rakyat dan memberdayakan masyarakat yang lemah dan tidak mampu sesuai martabat kemanusiaan dan negara bertanggung jawab atas fasilitas yang disediakan untuk kepentingan rakyat termasuk fasilitas umum dan fasilitas kesehatan (Pasal 34 UUD NRI 1945). Ketiga unsur dasar yaitu unsur sejarah, filosofi dan hukum tidak boleh dilepaskan dari konsep ideologi Pancasila yang akan diterapkan melalui BPIP. Karena ketiga unsur itu merupakan dasar yang harus diterapkan dan cita-cita yang harus dicapai oleh Negara Kesatuan Republik Indonesia.

\section{Simpulan}

Diundangkannya Peraturan Presiden No 7 Tahun 2018 tentang Badan Pembinaan Ideologi Pancasila, secara otomatis memberikan dwi fungsi status Pancasila sebagai dasar negara dan ideologi negara. Kekosongan hukum terkait substansi ideologi Pancasila dalam Perpres tersebut merupakan urgensi yang harus segera direformulasikan legalitasnya.

Kelak reformulasi ideologi tersebut harus memenuhi tiga aspek penting, terkait isi dan pelaksanaan pembinaanya. Aspek sejarah, Ideologi tersebut tidak boleh lepas dari akar pemikirannya yaitu gotong royong yang dicerminkan melalui sikap kemanusiaan, yang kelak melahirkan kesejahteraan dan keadilan sosial. Dari aspek filosofis cinta dan kasih harus diterapkan dalam pembinaannya karena itu merupakan kodrat manusia. Lima sila harus diterapkan bersamaan, tidak ada lagi penerapan beberapa sila saja, karena kelima sila itu saling berkaitan dan mengisi. Aspek yang terakhir adalah aspek hukum, ditempatkannya Pancasila sebagai dasar negara dan dicantumkan dibagian Pembukaan Undang-Undang Dasar Negara Republik Indonesia Tahun 1945 merupakan bukti nyata bahwa negara ingin melindungi dan memberikan payung hukum weltanschaung cita-cita pendiri bangsa. Ini bisa dijadikan contoh bahwa BPIP perlu melindungi substansi ideologi negara melalui prosedural hukum positif yang ada di Indonesia, karena jaminan akan domain substansi pembinaannya merupakan suatu kepastian hukum yang dapat dilindungi dan dipertanggungjawabkan. 


\section{Jurnal Cakrawala Hukum, Volume 11 No. 1 April 2020}

ISSN PRINT 2356-4962 ISSN ONLINE 2598-6538

Harapan ketika ketiga aspek tersebut direformulasikan adalah tidak ada lagi pernyataan dari BPIP yang mengkontradikisi nilai-nilai ketuhanan dan masyarakat Indonesia, terciptanya kembali sikap gotong royong antar warga negara dan kembalinya sikap kemanusiaan karena ini adalah gagasan yang digali oleh para pendiri bangsa. Kelak jika itu dilaksanakan akan tercipta suatu keadilan sosial dan kesejahteraan sosial yang bisa dirasakan oleh seluruh Bangsa Indonesia.

\section{Daftar pustaka}

Adams, Cindy. 2018. Bung Karno Penyambung Lidah Rakyat Indonesia. Jakarta. Yayasan Bung Karno.

Bhagi, Keo, Silvano. 2016. Negara Bukan-Bukan?. Yogyakarta. Ledalero.

Dhakidae, Daniel. 2001. Memahami Rasa Kebangsaan dan Menyimak Bangsa sebagai Komunitas-Komunitas Terbayang dalam Anderson, Benecdict. Imagined Communities. Yogyakarta. Insist Press dan Pustaka Pelajar.

Drijarkara, N. 1977. Pancasila dan Religi: Mencari Kepribadian Nasional. Bandung. Jemmars.

Drijarkara, N. 1980. Driyarkara tentang Negara dan Bangsa. Yogyakarta. Kanisius.

Hadiwijono, A. (2016). Pendidikan Pancasila, eksistensinya bagi mahasiswa. Jurnal Cakrawala Hukum, 7(1), 82-97. doi:10.26905/idjch.v7i1.1784
Hatta, Mohammad. 1978. Pengertian Pancasila. Jakarta. Inti Idayu Press.

https://www.vivanews.com/berita/nasional/37082sebut-agama-musuh-pancasila-kepala-bpipahistoris?medium=autonext diakses pada tanggal 16 Maret 2020

Khalik, Ridwan, Nur. 2018. Negara- Bukan-Bukan (Prisma Pemikiran Gusdur tentang Negara Pancasila). Yogyakarta. IRCiSod.

Nahudin, Y. (2017). Pemilihan umum dalam sistem demokrasi prespektif sila ke- 4 Pancasila. Jurnal Cakrawala Hukum, 8(2), 240-249. doi:10.26905/ idjch.v8i2.1670.

Peraturan Presiden Nomor 7 Tahun 2018 tentang Badan Pembinaan Ideologi Pancasila.

Poespowardojo, Soerjanto. 1989. Filsafat Pancasila: Sebuah Pendekatan Sosio-Budaya. Jakarta. Gramedia.

Syamsudin. M dkk. 2009. Pendidikan Pancasila Menetapkan Pancasila Dalam Konteks Keislaman dan Keindonesiaan. Yogyakarta. Total media.

Undang-Undang Dasar Negara Republik Indonesia Tahun 1945.

Wahana, Paulus. 1993. Filsafat Pancasila. Yogyakarta. Kanisius.

Wahid, Abdurrahman. 1991. Pancasila Sebagai Ideologi. Jakarta. BP7 Pusat.

www. Bpip.go.id/ diakses pada tanggal 1 Februari 2020. 